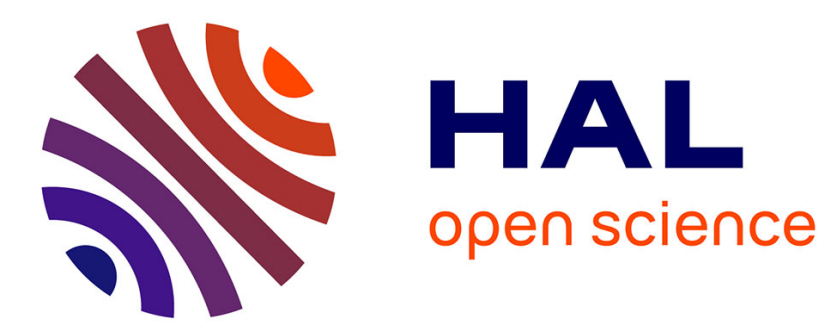

\title{
Structure and composition of MCrAlY coatings modified by $\mathrm{Al}$ additions
}

\author{
F. Brossa, D. d'Angelo, E. Gandini
}

\section{To cite this version:}

F. Brossa, D. d'Angelo, E. Gandini. Structure and composition of MCrAlY coatings modified by Al additions. Journal de Physique IV Proceedings, 1993, 03 (C9), pp.C9-559-C9-568. 10.1051/jp4:1993959 . jpa-00252399

\section{HAL Id: jpa-00252399 https://hal.science/jpa-00252399}

Submitted on 1 Jan 1993

HAL is a multi-disciplinary open access archive for the deposit and dissemination of scientific research documents, whether they are published or not. The documents may come from teaching and research institutions in France or abroad, or from public or private research centers.
L'archive ouverte pluridisciplinaire HAL, est destinée au dépôt et à la diffusion de documents scientifiques de niveau recherche, publiés ou non, émanant des établissements d'enseignement et de recherche français ou étrangers, des laboratoires publics ou privés. 


\title{
Structure and composition of MCrAlY coatings modified by $\mathrm{Al}$ additions
}

\author{
F. Brossa $\left({ }^{1}\right)$, D. D'Angelo $\left({ }^{2}\right)$ and E. Gandini $\left({ }^{3}\right)$

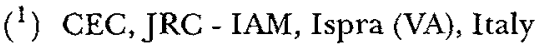 \\ $\left({ }^{2}\right)$ ENEL - CRTN, Milan, Italy \\ $\left({ }^{3}\right)$ ATLA - Turbine Components, Chieri (TO), Italy
}

\begin{abstract}
Plasma spray techniques have been used to increase the Al content on existing NiCoCrAIY films in order to obtain high temperature resistant coatings on Ni-base superalloys for gas turbine applications. Surface alloying has been produced by thermal diffusion under vacuum of the $\mathrm{Al}$ and MCrAlY films. This treatment reduces the surface roughness and increases the coating density by sealing its porosity. The aluminides formed have been analyzed in terms of their structural composition and oxidation resistance. Al additions are effective in reducing the oxidation rates, in particular for the MCrAlY coatings which are APS deposited. By increasing the temperature over $1100{ }^{\circ} \mathrm{C}$, the coating efficiency rapidly decreases.
\end{abstract}

\section{Introduction.}

Nickel base alloys are particularly suitable for use in harsh aggressive environments, e.g. in the hot sections of turbine engines, for the purpose of overcoming problems associated with thermal fatigue, cracking and distortion. By increasing the gas inlet temperature of the turbine, corrosion phenomena such as oxidation, sulphidation and volatile compound formation are accelerated. Thus, in order to extend the life-time of the components employed and to maintain their mechanical integrity, coatings are widely used [1-3]. The performance of high temperature resistant coatings on superalloys is connected to the coating structure, composition and interaction with the base materials [4-6].

Overlay MCrAlY alloys, deposited by means of plasma spray (PS) are more and more being adopted as protection against corrosive atmospheres. The coating efficiency depends on the capability of forming, at high temperatures, protective oxide films consisting of $\mathrm{Al}_{2} \mathrm{O}_{3}$. It is well known that the protective characteristics of these layers not only depend on their chemical composition but also on their structure and density [7-10]. A number of studies have confirmed that the degradation mechanisms are due to internal oxidation which is greater for the less dense films.

The object of this paper is to study the Al enrichment of the MCrAlY plasma sprayed coatings in order to:

1) increase the amount of $\mathrm{Al}$, the sacrificial element, on the external surface of the coatings and

2) increase the density of the protective layers, thus sealing the inherent pores by means of liquid Al diffusion. 


\section{Experimental procedure.}

2.1 SAMPLE PREPARATION. - The base materials employed were the superalloys UD 520, IN 738 and Nimonic 80A whose compositions are outlined in table I. These materials were supplied in cylindrical and bar form and were subsequently solution annealed and aged according to the specifications of the manufacturer. The samples were then sand blasted with new corundum of mesh size 220 under a pressure of 6 bars and rinsed immediately in acetone before being coated. The coating chosen for this work was a NiCoCrAlY alloy, Amdry 995. It was supplied by AMI and its composition is also given in table I. This alloy is particularly suitable for withstanding oxidation at elevated temperatures. The techniques used for the deposition of the NiCoCrAlY was air plasma spraying (APS) and vacuum plasma spraying for the $\mathrm{Al}$ in most cases. These techniques were chosen for economic reasons in view of present industrial applications.

Table I. - Chemical composition of base materials and coatings.

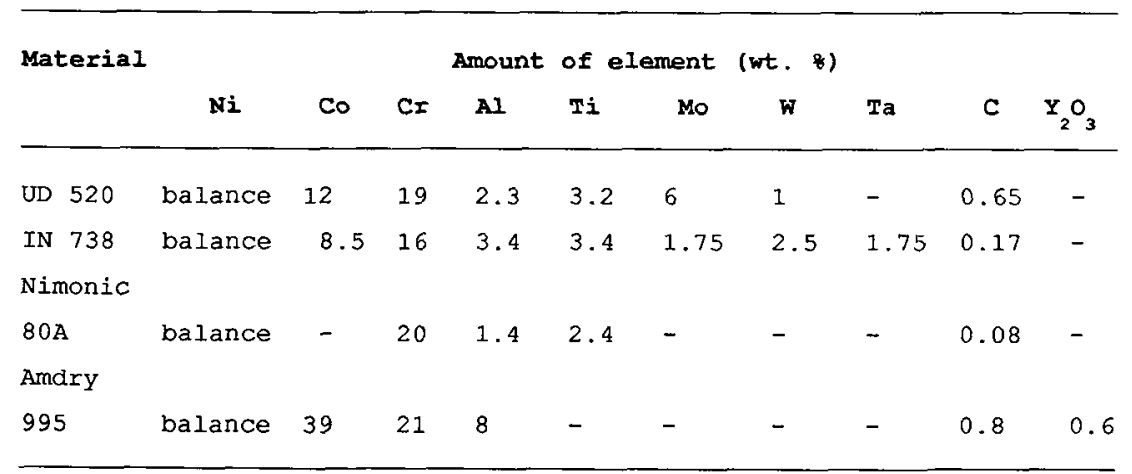

Figure 1 shows the section of a coating consisting of Amdry 995 (APS) and Al (VPS) before being heat treated. Topographical views of this sample before and after the deposition of $\mathrm{Al}$ are displayed in figure 2.

2.2 OXIDATION TESTING IN AIR. - Cylindrical samples of $10 \mathrm{~mm}$ diameter and $50 \mathrm{~mm}$ height with rounded heads (Fig. 3) were completely coated with Amdry 995 using a VPS process. Half of the samples were vacuum heat treated at $1080^{\circ} \mathrm{C}$ for 1 hour and the remainder were left untreated. Following this, the samples were covered with an homogeneous layer of Al using a VPS technique which deposited a thickness which was approximately one third of the thickness of the Amdry 995 layer. Surface alloying of the Al on the substrate NiCoCrAlY was carried out under vacuum at $920^{\circ} \mathrm{C}$ for 3 hours.

The effect of the $\mathrm{Al}$ treatment was determined by comparing the cyclic oxidation performance of Al-treated specimens to those coated only with the NiCoCrAlY. The oxidation test was conducted in air; after $6 \mathrm{~h}$ exposures, the specimens were removed from the furnace, allowed to cool, weighed and returned to the furnace. This procedure was repeated until the exposure totaled 48 hours, and thereafter the cyclic time was increased to 12 hours. 


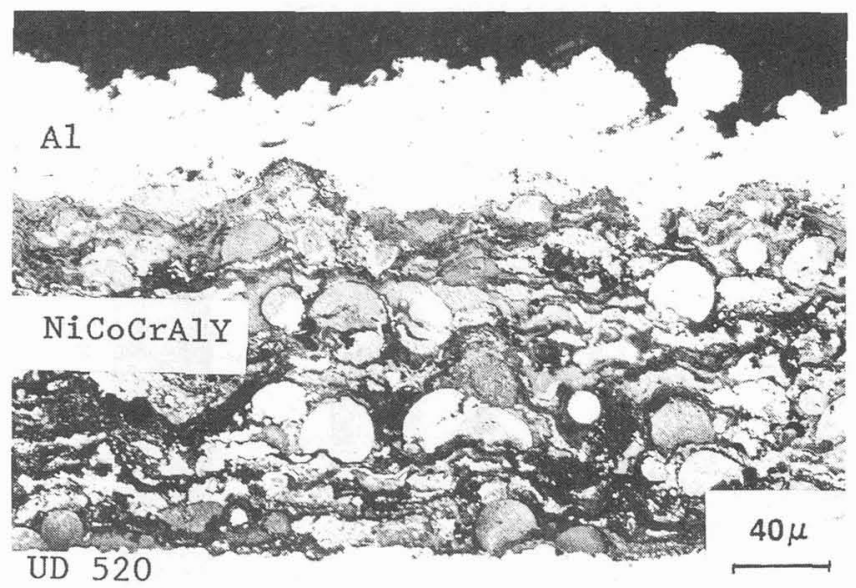

Fig. 1. - Cross-section of UD 520 with Amdry bond-coat APS deposited and an Al film VPS deposited. Sample not heat treated.
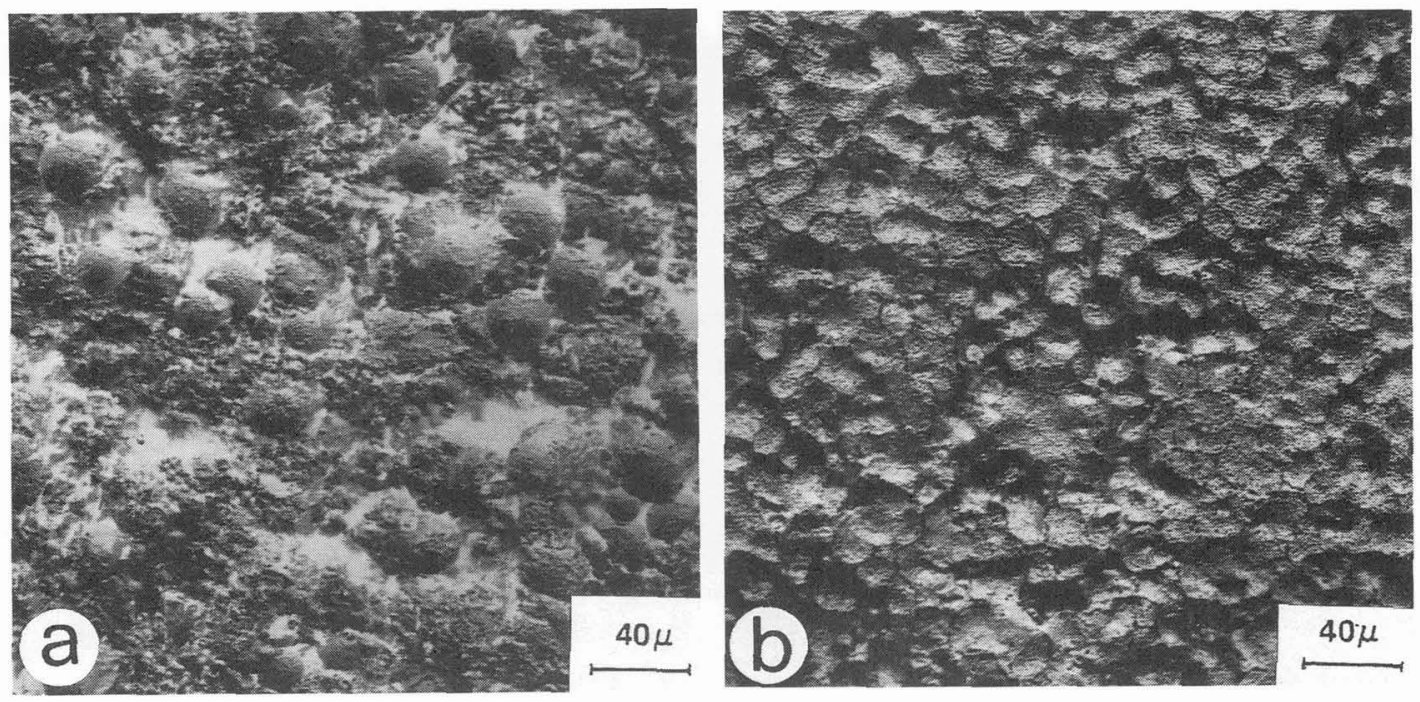

Fig. 2. - Topographical views of the sample shown in figure 1: a) before $\mathrm{Al}$ deposition; b) after $\mathrm{Al}$ deposition.

Tests were performed at $1100^{\circ} \mathrm{C}$ and $1300^{\circ} \mathrm{C}$. Both of these temperatures are considerably higher than this alloy/coating system would be exposed to in practice, but it is hoped that useful information could be developed in a relatively short time. 

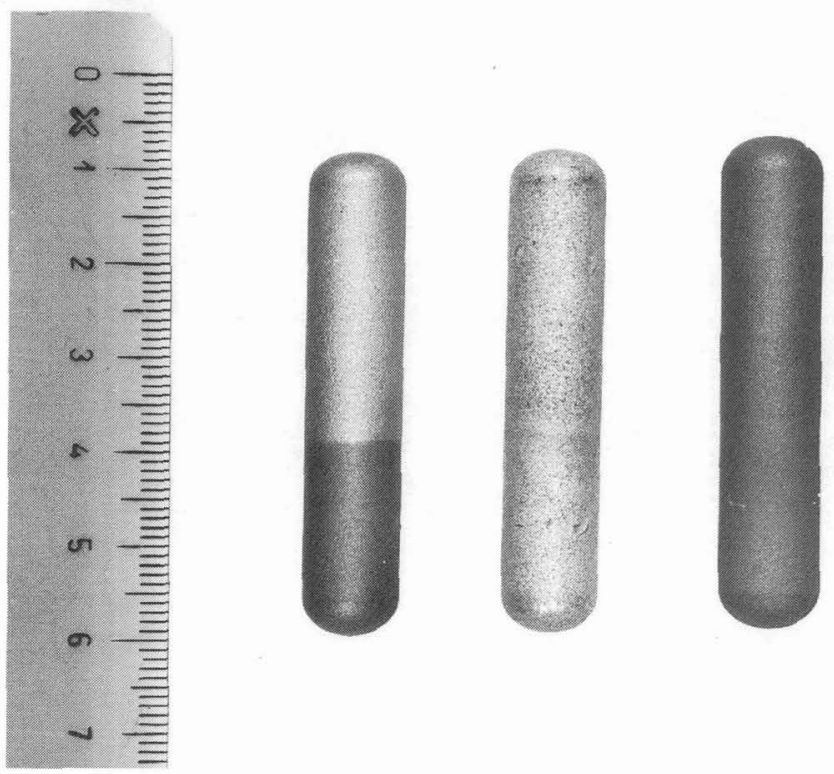

Fig. 3. - Cylindrical samples used for oxidation tests.

Table II. - Spraying data for powder Amdry 995 and Al Metco 54.

\begin{tabular}{|c|c|c|c|c|c|c|}
\hline \multirow[b]{3}{*}{ Chamber pressure } & \multicolumn{4}{|c|}{ Andry 995} & \multicolumn{2}{|c|}{ Al Metco 54} \\
\hline & \multicolumn{2}{|c|}{ Sputtering } & \multicolumn{2}{|c|}{ Spraying } & & \\
\hline & 20 & $\mathrm{mb}$ & 150 & mo & 150 & mo \\
\hline Distance & 240 & $\mathrm{~mm}$ & 225 & $m$ & 240 & $\mathrm{~mm}$ \\
\hline Primary gas Ar & 40 & slpm & 50 & slpm & 50 & slpm \\
\hline Secondary gas $\mathrm{H}_{2}$ & 1 & slpm & 5 & slpm & 1 & slpm \\
\hline Carrier gas Ar & & - & 1.7 & slpm & 2.2 & slpm \\
\hline Arc current & 300 & A & 600 & A & 600 & $A$ \\
\hline Sputtering current & 40 & A & & - & & - \\
\hline Arc voltage & 43 & $\mathrm{~V}$ & 61 & $\mathrm{~V}$ & 45 & $\mathrm{~V}$ \\
\hline Powder feed & & - & 20 & $\mathrm{~g} / \mathrm{min}$ & 4 & $\mathrm{~g} / \mathrm{min}$ \\
\hline
\end{tabular}

\section{Results and discussion.}

The alloying treatment of $\mathrm{Al}$ greatly modifies the surface morphology of plasma spray coatings. The surface roughness, Ra, of the film after deposition and before the glass peening 
operation is linked to the plasma spray conditions: $\sim 15-20 \mu \mathrm{m}$ for APS coatings and $\sim 10$ $15 \mu \mathrm{m}$ for VPS coatings. The alloying treatment reduces the surface roughness of the APS and VPS coatings to a value between $4 \sim 8 \mu \mathrm{m}$ Ra. The APS deposited NiCoCrAlY substrate, resulting in a reduction in the level of porosity. The depth of this penetration depends upon the temperature, the time and the quantity of $\mathrm{Al}$ added. Figure 4a shows a cross section of the APS coating after a thermal treatment under vacuum at $1080^{\circ} \mathrm{C}$ for 6 hours. Figure $4 \mathrm{~b}$ displays the same sample subjected to a similar treatment for 108 hours. The thicknesses of the coatings before diffusion were $170 \mu \mathrm{m}$ for the Amdry NiCoCrAlY 995 and $60 \mu \mathrm{m}$ for the Al. Figure 4 shows how the melting and migration of Al into NiCoCrAlY produces a flattened surface and closes the porosity of the APS layer. Increasing the thermal treatment time up to 108 hours has little effect on the NiAl layer thickness, but has an effect on the interaction between the NiCoCrAlY layers and IN 738. Figure 5 illustrates a sample with a film of NiCoCrAlY (thickness $500 \mu \mathrm{m}$ ) produced by VPS and a second film of Al (thickness $180 \mu \mathrm{m}$ ) deposited by APS, which was thermally treated for 72 hours at $1080^{\circ} \mathrm{C}$. These samples were analysed using SEM and optical microscopy.
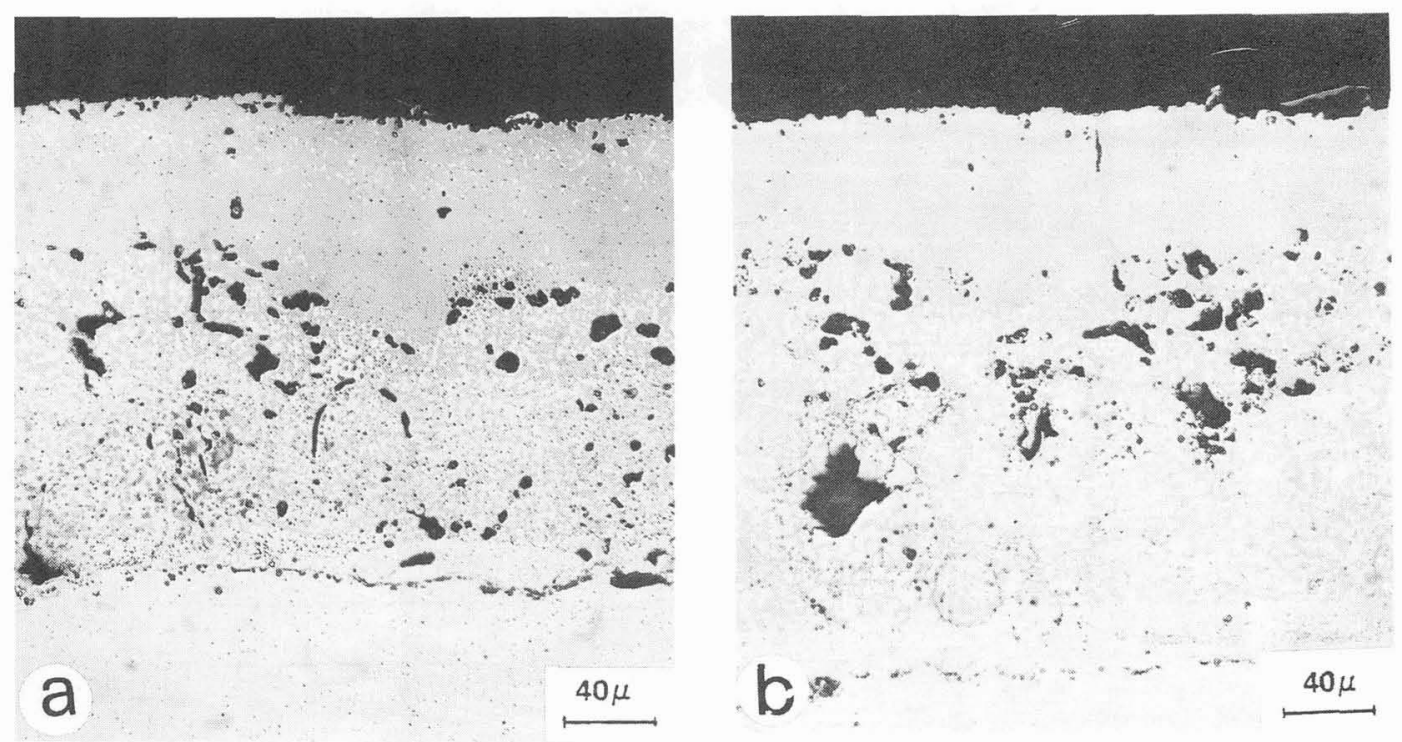

Fig. 4. - Cross-section of IN 738 with a Amdry $995 \mathrm{NiCoCrAlY}$ underlayer and an Al outer layer, both films APS deposited: a) after treatment at $1080^{\circ} \mathrm{C}$ for $6 \mathrm{~h}$; b) after a diffusion treatment at $1080^{\circ} \mathrm{C}$ for $108 \mathrm{~h}$.

A metallographic etch consisting of $\mathrm{HF}, \mathrm{HNO}_{3}$ and glycerine in equal quantities was used to reveal the phases produced by the interdiffusion between Al, NiCoCrAlY and the base material.

Table III shows the chemical composition as determined by EDS analysis at different points throughout the cross-section (NiCoCrAlY $+\mathrm{Al}$ ).

There is a concentration gradient of $\mathrm{Al}$ which extends from the outer surface towards the inner without exhibiting abrupt variations in composition. At the outer surface of the coatings 


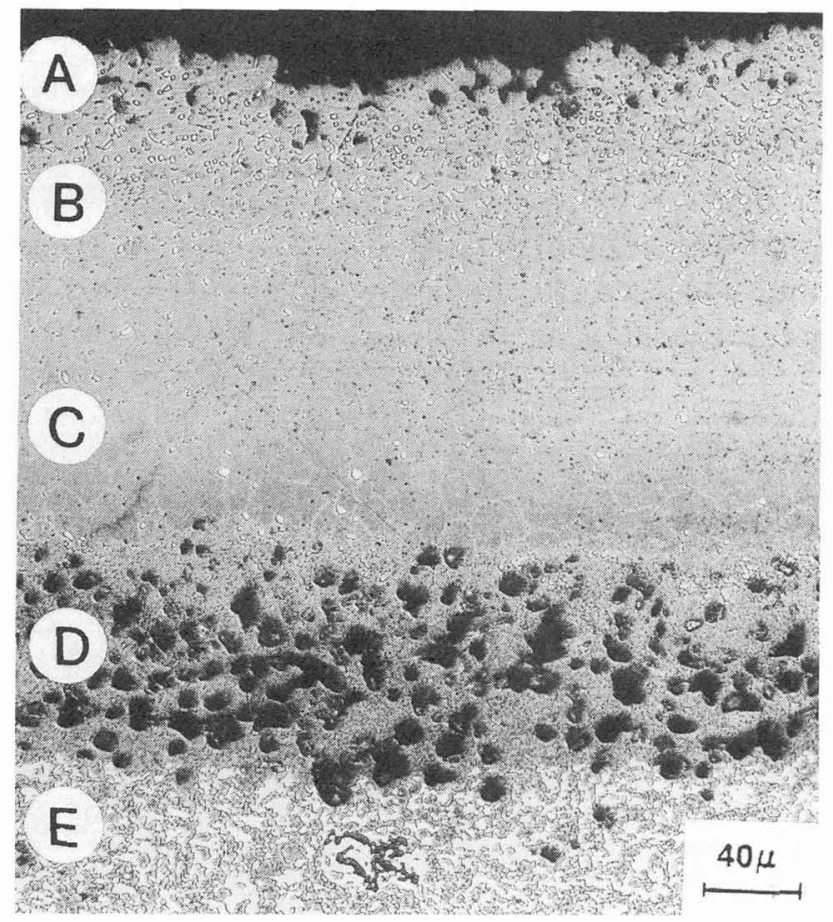

Fig. 5. - Cross-section of a VPS deposited NiCoCrAlY coating $500 \mu \mathrm{m}$ thick, coated with an Al APS film $180 \mu \mathrm{m}$ thick and vacuum heat treated at $1080^{\circ} \mathrm{C}$ for $72 \mathrm{~h}$.

Table III. - EDS analysis of the phases produced by interdiffusion $\mathrm{Al} / \mathrm{NiCoCrAlY}$ at $1080^{\circ} \mathrm{C}$ for $4 h$ sample shown in figure 5.

\begin{tabular}{crrrrr}
\hline Element & A & B & C & D & E \\
\hline Al & 25.81 & 22.79 & 20.59 & 11.60 & 6.53 \\
Si & 0.30 & 0.08 & 0.08 & 0.23 & - \\
Cr & 10.35 & 16.05 & 9.30 & 21.88 & 25.33 \\
Fe & 0.79 & 0.24 & 0.29 & 0.14 & 0.22 \\
Co & 33.74 & 33.16 & 32.70 & 32.57 & 40.02 \\
Ni & 28.31 & 27.09 & 36.35 & 32.95 & 27.47 \\
\hline
\end{tabular}

(Fig. 5, point A) there is a very brittle thin layer which $\mathrm{X}$-ray analysis characterized as $\mathrm{Ni}_{2} \mathrm{Al}_{3}$. The porous zone observed at point $\mathrm{D}$ is caused by the Kirkendall effect occurring during the inter diffusion of the two coatings and it is connected with the high quantity of the Al deposited on the NiCoCrAlY films.

Another series of samples were produced by depositing, on IN 738, a $250 \mu \mathrm{m}$ thick coating of NiCoCrAlY followed by a thermal bonding treatment at $1080^{\circ} \mathrm{C}$ for 4 hours and then, an $80 \mu \mathrm{m}$ layer of $\mathrm{Al}$ by VPS. Figure $6 \mathrm{a}$ indicates a section of this specimen after an alloying 

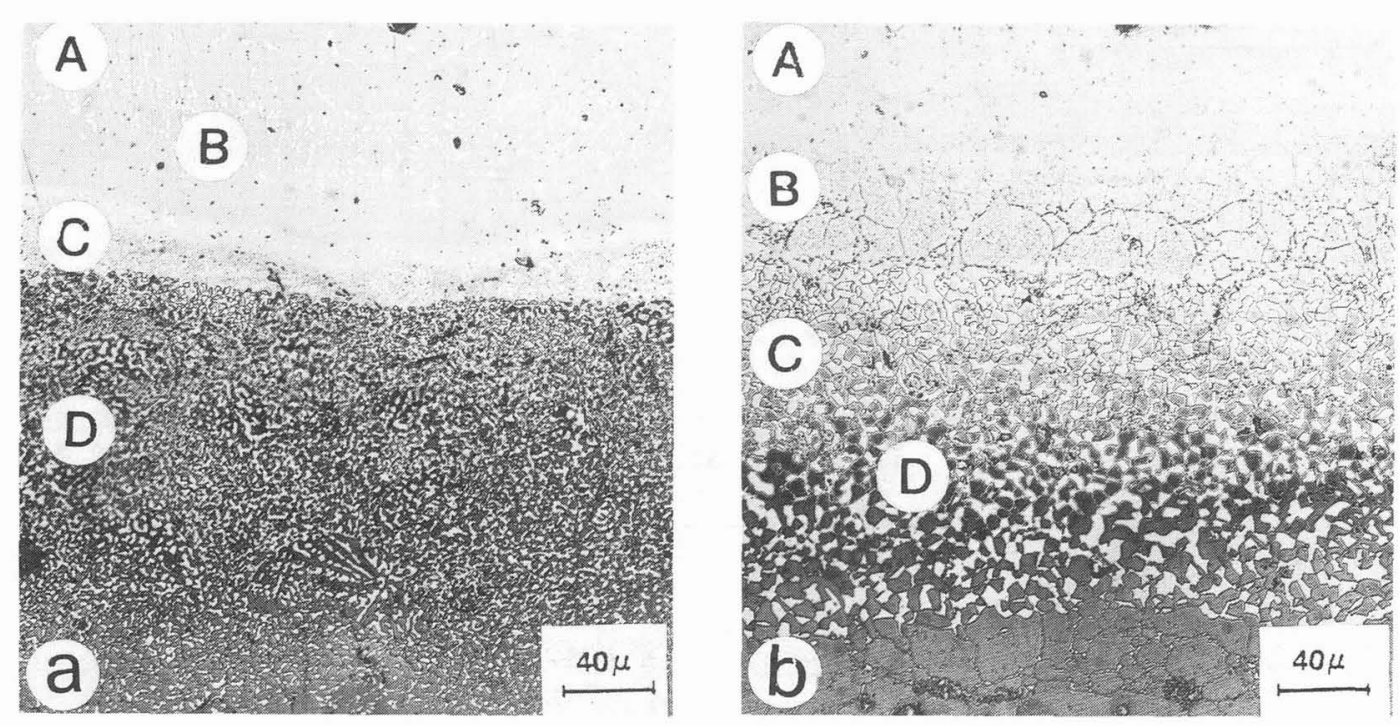

Fig. 6. - Cross-section of IN 738 with an inner coating of VPS deposited NiCoCrAlY $250 \mu \mathrm{m}$ thick, and an outer Al layer $80 \mu \mathrm{m}$ thick followed by: a) alloying treatment at $1000^{\circ} \mathrm{C}$ for $1 \mathrm{~h}$; b) diffusion treatment $1200^{\circ} \mathrm{C}$ for $12 \mathrm{~h}$.

Table IV. - EDS analysis of the diffusion layer produced by thermal treatment at $1000^{\circ} \mathrm{C}$ for $1 \mathrm{~h}$. Sample shown in figure 6 a.

\begin{tabular}{crrrr}
\hline Element & A & B & C & \multicolumn{1}{c}{ D } \\
\hline AI & 34.47 & 30.23 & 31.59 & 11.65 \\
$\mathrm{Si}$ & 0.51 & 1.18 & 0.67 & 0.15 \\
$\mathrm{Ti}$ & 0.11 & - & - & 0.04 \\
$\mathrm{Cr}$ & 8.47 & 21.24 & 9.31 & 22.64 \\
$\mathrm{Fe}$ & 0.25 & 0.08 & 0.10 & 0.08 \\
$\mathrm{Co}$ & 28.80 & 23.97 & 30.42 & 35.76 \\
$\mathrm{Ni}$ & 27.12 & 23.17 & 27.67 & 29.55 \\
$\mathrm{Cu}$ & 0.28 & 0.13 & 0.25 & 0.14 \\
\hline
\end{tabular}

treatment of 1 hour at $1000^{\circ} \mathrm{C}$ under vacuum. Table IV shows the compositions in the different zones obtained by EDS analysis for the sample shown in figure 6a. Application of an $\mathrm{Al}$ coating $80 \mu \mathrm{m}$ thick followed by an annealing at $1000^{\circ} \mathrm{C}$ for 1 hour produces an homogeneous diffusion layer. The thickness of this layer increases slightly with prolonged heat treatments. A cross-section of an identical sample subjected to a thermal treatment at $1200^{\circ} \mathrm{C}$ for 12 hours is seen in figure $6 \mathrm{~b}$. Table $\mathrm{V}$ indicates the compositions of each zone of the sample $6 \mathrm{~b}$. It can be deduced (from EDS analysis) that in phase A, the level of $\mathrm{Cr}$ has been reduced due to evaporation, probably in the form of $\mathrm{CrO}_{3}$, at the high temperatures. 
Table V. - EDS analysis of the diffusion layer produced by a thermal treatment at $1200^{\circ} \mathrm{C}$ for $12 \mathrm{~h}$. Sample shown in figure $6 b$.

\begin{tabular}{lrrrr}
\hline Element & \multicolumn{1}{c}{ A } & \multicolumn{1}{c}{ B } & \multicolumn{1}{c}{ C } & D \\
\hline AI & 32.05 & 22.54 & 13.13 & 21.21 \\
Si & 1.16 & 1.28 & 0.90 & 0.28 \\
Ti & 0.04 & 0.07 & 0.05 & 0.95 \\
Cr & 1.99 & 11.02 & 24.40 & 9.65 \\
Fe & 0.32 & 0.10 & - & - \\
Co & 34.29 & 31.94 & 33.92 & 21.93 \\
Ni & 30.04 & 32.71 & 27.60 & 45.82 \\
Cu & 0.10 & 0.34 & - & 0.15 \\
\hline
\end{tabular}

No porous zone was detected with the $80 \mu \mathrm{m}$ thick Al film.

Oxidation kinetic curves for the four samples coated with a NiCoCrAlY layer but not heat treated before $\mathrm{Al}$ deposition are displayed in figure $7 \mathrm{a}$. Figure $7 \mathrm{~b}$ illustrates similar curves for the heat treated samples. The weight gain at the temperature of $1100^{\circ} \mathrm{C}$ is higher for the aluminised samples during the first 100 hours but, for longer times, this difference is reduced.

As can be seen from figure 7, the behaviour of NiCoCrAIY coatings both with and without subsequent $\mathrm{Al}$ coatings at $1300^{\circ} \mathrm{C}$ is unsatisfactory. Although the behaviour of the Al treated coating is significantly better than the untreated one, both show significant spallation after 50 hours. This might be due to the removal of $\mathrm{Cr}$ in the form of $\mathrm{CrO}_{3}$.

However, the beneficial effects of the $\mathrm{Al}$ additions to the NiCoCrAlY coatings are very evident in the oxidation tests performed at $1100^{\circ} \mathrm{C}$ for long durations. Samples of IN 738 VPS coated with NiCoCrAlY in cyclic oxidation tests collapsed after 800 hours, whereas, the same samples with $\mathrm{Al}$ additions withstood the same test conditions for at least 2000 hours.

\section{Conclusions.}

The results described above can be summarized as follows:

1) The surface roughness parameter is reduced by $\mathrm{Al}$ alloying.

2) Due to the $\mathrm{Al}$ diffusion process, the pores in the NiCoCrAlY layer are sealed, i.e. the porosity level is reduced.

3) There is no difference between the results obtained by the varying processes, namely APS and VPS, when employed for Al deposition.

4) Bonding thermal treatment contributes to a low porosity level and hence, results in increased oxidation resistance.

5) $\mathrm{Al}$ additions are particularly effective in reducing the oxidation rates of the porous MCrAlY coatings which are APS deposited. 

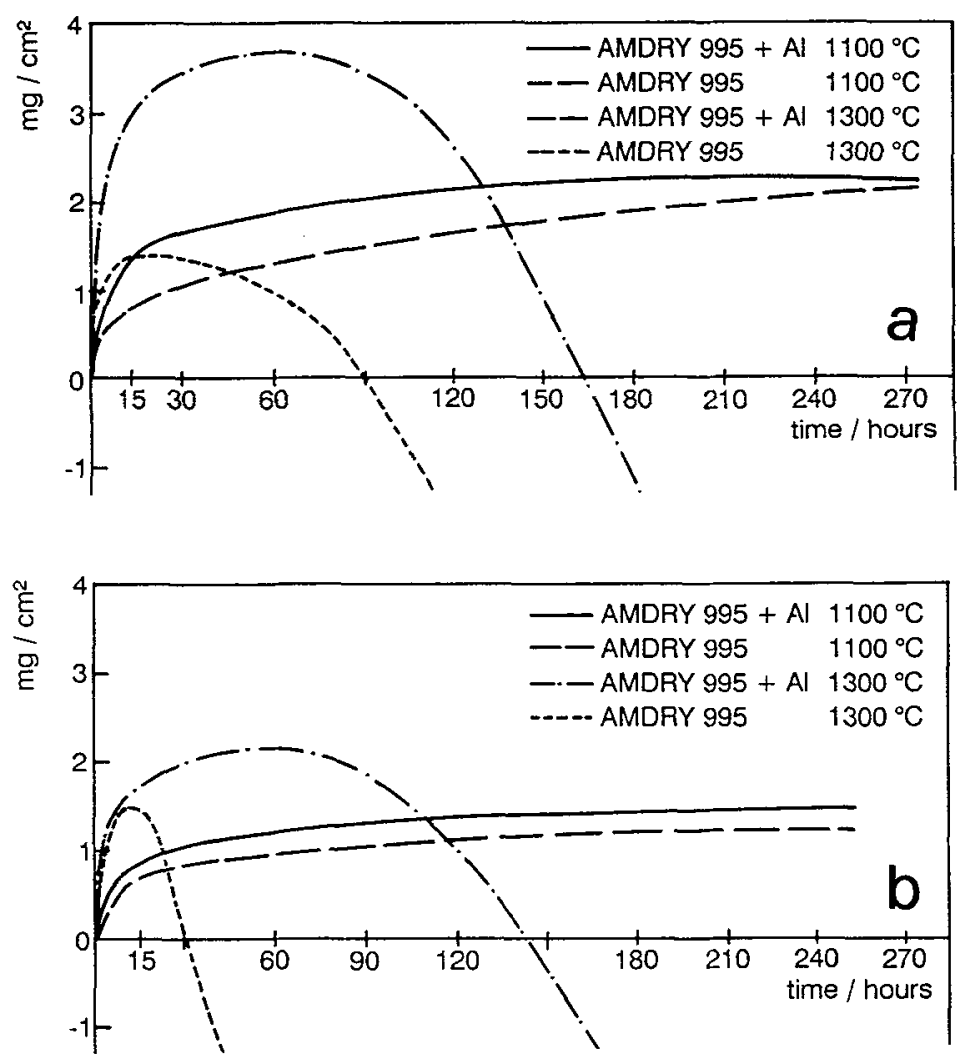

Fig. 7. - Cumulative weight loss $(\mathrm{mg} / \mathrm{cm} 2)$ vs time (hours) produced by air oxidation tests at $1100{ }^{\circ} \mathrm{C}$ and $1300^{\circ} \mathrm{C}$ for NiCoCrAlY deposition $\left(1080^{\circ} \mathrm{C}\right.$ for $\left.4 \mathrm{~h}\right)$ and then coated with Al VPS deposited.

6) The VPS NiCoCrAlY coatings on IN 738, vacuum annealed at $1080^{\circ} \mathrm{C}$ for 4 hours in the cyclic oxidation test at $1100^{\circ} \mathrm{C}$ failed after 600 hours.

7) The VPS NiCoCrAlY coatings modified by an Al overcoat exhibited favourable behaviour for at least $2000 \mathrm{~h}$.

8) Neither coating was acceptable at $1300^{\circ} \mathrm{C}$.

\section{Acknowledgements.}

Part of this work was performed under a research contract between ENEL-CRTN and JRCIAM Ispra Laboratory. 


\section{References}

[1] ChANDLER P.E., Thermal Spraying Processes and Applications, Welding and Allied Developments for the Process Industries (The Welding Institute, April 1988).

[2] Meier G.H., Mater. Sci. Eng. A 120 (1989) 1-12.

[3] Pettit F.S., Giggins C.S., C.T. Sims, N.S. Stoloff, W.C. Hagel Eds., Superalloys II (Wiley, New York, 1987) Chapt. 12.

[4] MÉVRel R., Mater. Sci. Eng. A 120 (1989) 13-24.

[5] RHYS-JONES T.N., Mat. Sci. Technol. 4 (1988) 421-430.

[6] Meetham G.W., The Development of Gas Turbine Materials (Applied Science Publishers, Barking, UK, 1981).

[7] NASR H., Some Areas of Application of Plasma Spray Coatings in the Field of Aviation, Proc. of 1st Plasma-Technik-Symposium (Lucerne, Switzerland, May 1988, Vol. 3) 75-84.

[8] Pizzi P., Tarditi P.L., Tosto S., Ramous E., MatTeazzi P., Mat. Sci. Eng. 54 (1982) $1-7$.

[9] STRINGER J., Mat. Sci. Eng. A 120 (1989) 129-137.

[10] WU W., STREIFF R., WANG M., Mat. Sci. Eng. A 121 (1989) 499-507. 